\title{
Research on methods, techniques and technologies of carbon sequestration in soil
}

\author{
Oana Diana Cristea ${ }^{1}$, Valentin Vlăduț ${ }^{1 *}$, Nicoleta Ungureanu ${ }^{2}$, Diana Lorena Popa ${ }^{2}$, \\ Simona Isticioaia ${ }^{3}$, Liliana Dumitrescu ${ }^{4}$, Gheorghe Matei $^{5}$ and Livia Apostol ${ }^{6}$ \\ ${ }^{1}$ The National Institute of Research - Development for Machines and Installations Designed to \\ Agriculture and Food Industry - INMA Bucharest/ Romania \\ ${ }^{2}$ University POLITEHNICA of Bucharest \\ ${ }^{3}$ Agricultural Research and Development Station Secuieni, 371 Principală Street, Neamț, Romania \\ ${ }^{4}$ INOE 2000-IHP, street Cutitul de Argint, no. 14, Sector 4, Bucharest, Romania \\ ${ }^{5}$ University of Craiova (Romania) \\ ${ }^{6}$ National Research and Development Institute for Food Bioresources (Romania)
}

\begin{abstract}
Soil is one of the natural reservoirs of the carbon biogeochemical cycle, incorporating approximately 6000 billion tons of carbon. Given that with the industrial development more and more carbon is emitted into the atmosphere, solutions, technologies and methods are being sought to reduce this carbon or, where appropriate, it is not eliminated into the atmosphere. The purpose of this paper is to study and identify the simplest methods to be applied in agriculture, for soil processing, by identifying the techniques, technologies and equipment to achieve this without turning the furrow, so that the carbon incorporated in the soil by plants remains sequestered there.
\end{abstract}

\section{Introduction}

The effects of climate change have had effects in all areas of industry. On this subject, in 2015, the " 4 per 1.000 initiative: soils for food security and climate it was achievable with the aim of sequestering the organic carbon of the soil. It had the main objectives: reducing climate change, improving food security and adapting globally to climate change. Also, the Paris Agreement to request the reduction the global warming below $2^{\circ} \mathrm{C}$. [1, 2].

The conclusion is that rapid decomposition is due to soil works which is also the main cause of short-term $\mathrm{CO} 2$ emissions. Being introduced by tillagesoil organic matter damage is determined by both soil moisture and temperature, also the dimensions of quality and quantity of organic carbon in the soil [3, 5]. Nevertheless, Research colleagues have invented higher NT emissions compared to the revised batches distributed to the decomposition of the oldest surface residues [5, 6]. Also, recently, some researchers reached the conclusion that reduction of $\mathrm{CO} 2$ emissions after the seeding process [7] of the no-till emission. The researchers used time emissions and exponential delimitation over time as a significance for estimating soil $\mathrm{CO} 2$ emissions.

There are a variety of methods which can be used in order to determine the carbon stocks in the aboveground biomass [8-10]. Even though botth contact field measurements and contactless measurement use remote sensing, the Contact measurement methods are costly

${ }^{1}$ Corresponding author: valentin_vladut@yahoo.com 
and time consuming, but the results are more accurate. Therefore, for large areas, the contact methods are almost unusable [11-14]. Conservation soil use (i.e. no-fill, minimum tillage) has had a positive impact in the areas of food security, biodiversity and water quality. the recommendation to improve the stocks of organic carbon (SOC) and total nitrogen (STN) in the soil, and even though the results were mainly reported to be encouraging with a warm climate, with rain crops and low percentage of fertilization with $\mathrm{N}$, it represents an improvement in our efforts to conservate the environment [15].

For instance, in the United States, only 12 percent of total carbon dioxide emissions from the energy, transportation and industrial sectors are cloistered by the forest and croplands of the territory. Figure 1, transposed from the EPA, exemplifies processes in various forms by which trees and soils gain or lose carbon [16-18].

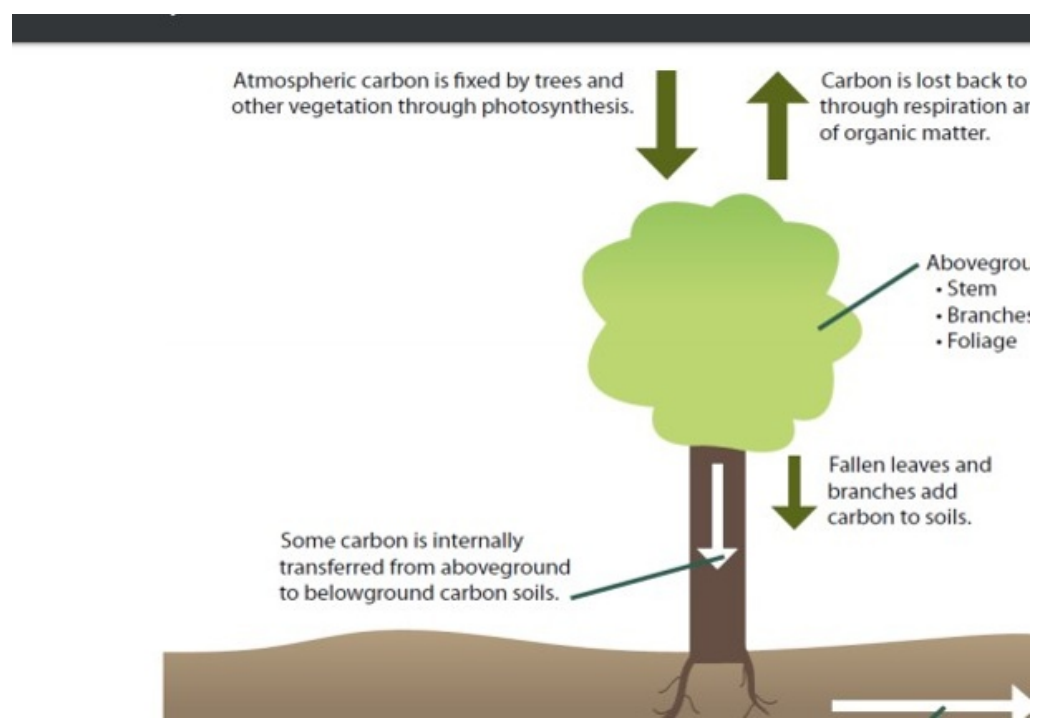

Fig. 1. Carbon pools in forestry and agriculture [18]

The already mentioned "4\%o initiative: Soils for food security and climate" from 2015 Paris, is based on the premise that achieving food security and combating climate change are complementary. Therefore, its aim is to ensure that agriculture forwards solutions to combat the climate change [19], one of them being the increase of the soil carbon pool to offset national greenhouse gas emissions from fossil fuel combustion. The initiative also implies a voluntary action plan under the Lima Paris Agenda for Action (LPAA), and is backed up by a strong and ambitious research program [20].

Currently, all industrial carbon sequestration projects are evaluated using the Life Cycle Analysis (LCA) methodology, which takes into account the environmental impact of land use, even if carbon sequestration is not done in soil. However, carbon sequestration in the soil probably offers the chance for the greatest technological and environmental revolution ever [21]. Globally, the carbon content is about twice as high in the soil as in the atmosphere and three times as high as in the vegetation. Europe's soils are a huge reservoir of carbon, containing about 75 billion tons of organic carbon. When organic matter is formed, $\mathrm{CO}_{2}$ is taken up from the atmosphere; reversely, when the organic matter in the soil decomposes, it releases carbon dioxide $\left(\mathrm{CO}_{2}\right)$ into the atmosphere [21].

The potential for carbon sequestration in the soil is mainly verified by pedological factors that specify the maximum physico-chemical limit for carbon storage in the soil. Amongst the major factors (Fig. 2), we can use together the texture of the soil and the clay mineralogy, the proportion of coarse fragments, the depth, the bulk density [21]. 


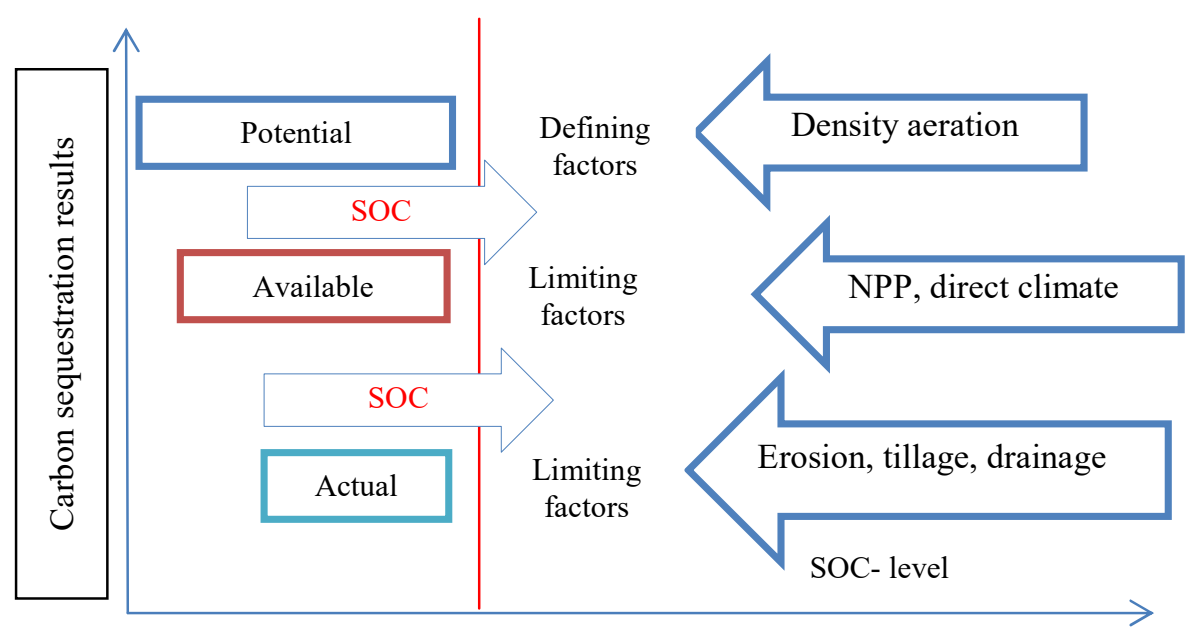

Fig. 2. Factors affecting soil carbon sequestration

The carbon sequencing obtained was defined by several factors that will determine the carbon intake in the soil system. One of the leading factor is change in photosynthesis rate minus autotrophic respiration (NPP) Practices used to manage land that increase carbon sequestration by supplementing NPPs tend to raise the level reached to be closer to the potential level, thus showing that a climate has direct and indirect effects over achievable sequestration. [23-24].

Compared to natural vegetation, agricultural soils contain less organic carbon in the soil (SOC), due to the removal of plant material as part of the crop, which itself contains carbon. As a result, agricultural soils have about 30-40\% less SOC than soils with natural vegetation. Obviously, not all agricultural land could be converted back into natural vegetation because food must be produced, but changing agricultural practices could increase the amount of SOC contained in agricultural soils. This is called carbon sequestration in the soil, which signifies taking $\mathrm{CO} 2$ from the atmosphere and capturing it in the soil [25].

The agricultural practices that determine the increase of $\mathrm{CO}_{2}$ emissions from the soil are varied: plowing works, deforestation, drainage of organic soils / peatlands, subsistence agriculture that determines the depletion of fertility, overgrazing etc. In the soil mineralization of organic carbon is strongly dependent on temperature, therefore global warming can increase $\mathrm{CO}_{2}$ emissions into the atmosphere. Loosening the soil through agricultural work leads to losses of carbon and nitrogen from the soil due to increased accessibility of oxygen needed to break down organic matter and respiration, thus increasing the release of $\mathrm{CO}_{2}$. The application of conservation works leads to an accumulation of carbon and organic matter in agricultural [26].

Recommended measures include: the transition to no-tillage management system; if an agricultural work is required, it is recommended to avoid autumn works and wait until spring; reducing the number of crossings of agricultural machinery on the soil, the use of chisel and discs only in the upper layer of the soil; the operation of agricultural equipment at lower speed [26].

The decomposition rate increases with temperature and decreases with increasingly anaerobic conditions. The dynamics of SOC pool are with a strong influence on soil management practices and which are dependent on the balance between the input carbon (C) and the output by different methodss [23-24]. 


\section{Research Methods}

The agricultural practices that determine the increase of $\mathrm{CO} 2$ emissions from the soil are varied: plowing works, deforestation, drainage of organic soils / peatlands, subsistence agriculture that determines the depletion of fertility, overgrazing, etc. The method of mineralization of organic carbon in the soil is strongly dependent on temperature, therefore global warming can increase $\mathrm{CO} 2$ emissions into the atmosphere.

Soil temperature measurement (if the no-tillage system will be applied on $76 \%$ of the arable land), is done by installing temperature sensors, the simplest of which can be made from a junction of two metals with different properties (for example a nickel-constant thermocouple). Thus, it should be noted that Figaro type oxygen sensors generate a voltage of the order of millivolts, so the accuracy of reading the datalogger must be greater than one tenth of a millivolt, and for thermocouples an accuracy of hundreds of $\mathrm{mV}$ is needed $[27,28]$.

Figure 3 shows a system with three sets of sensors, at three different depths $(4,8$ and 22 $\mathrm{cm})$. The number of sensor sets and their depths can be chosen depending on the purpose of the study, the specific conditions of moisture, temperature, vegetation and the limitation due to the physical dimensions of the sensors. Thus, for the strict determination of the flow at the soil surface, a set of sensors is sufficient, located at a depth between 7 and $10 \mathrm{~cm}$, the concentration gradient considered in this case being the one between the surface, where the concentration of $\mathrm{CO}_{2}$, respectively $\mathrm{O}_{2}$, can be considered constant and measurement depth, where the concentration will be recorded by direct measurement [28].
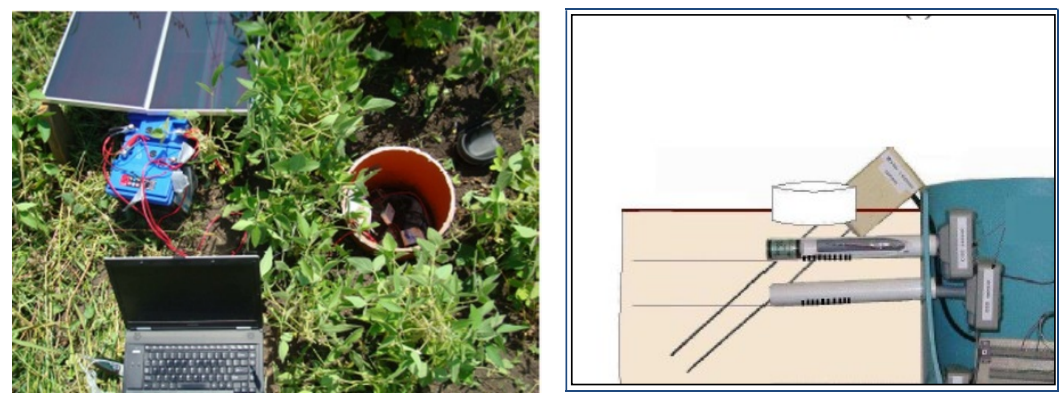

Fig. 3. Overview and section of the monitoring system of $\mathrm{CO}_{2}, \mathrm{O}_{2}$, moisture and temperature in the soil, based on the gradient method [28]

In order to achieve higher aggregate breakdown and smaller soil aggregate sizes, three optional passes of the rotary tiller have been used and the work to be cultivated has been carried out by means of a tractor having an engine power of $77,3 \mathrm{~kW}$, which had a speed of movement before $3.5 \mathrm{~km} \mathrm{~h}-1$ and a rotary tipper with $2.5 \mathrm{~km} \mathrm{~h}-1$. Prior to the works, the batches without traces of culture residues were removed. Two days before, the residues had been on the surface of the soil since the harvest period The vast majority of residues were incorporated into the soil about $0.20 \mathrm{~m}$ long before and $0.05 \mathrm{~m}$ after the soil [29].

Two efficient methods use to determine SOC have been evaluated and compared, the obtained data showing interesting results. One of the methods used is the "wet" Thurin method in modifying Nikitin (TN). At the last, "dry" measurement of the SOC was performed using the $\mathrm{CN}$ analyzer (EA), was performed on 95 soil samples from 17 sampling sites with a wide range of SOC (1-15\%). The process of stealing samples from sites that include arable land and meadows main soil types and subtypes of Slovakia. The statistics processed revealed that the differences between the two methods are minimal in the case of a parcel of soils with the SOC content up to 3\%. [30]. 
Percentage of $\mathrm{C}$ loss due to emission factors caused by soil or crop residues, could be easily summed up in accordance with the assumptions described above. Figure no. 2 presents the emission factors associated with the loss of $\mathrm{C}$ from crop residues in the second-year experiment. The tillage system that proved itself to cause the greatest relative loss when it comes to the additional $\mathrm{CO} 2-\mathrm{C}$ from the residue was MP, which led to an equivalent decrease of approximately $3.99 \%$ of $\mathrm{C}$ in emissions over a short period of time [29].

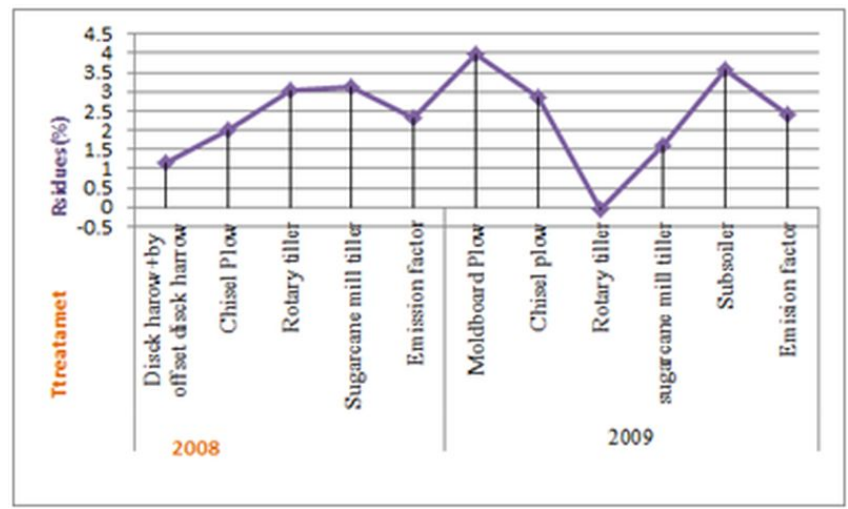

Fig.4. The main emission factors of the soil for each of the cultivation systems that were analyzed (years $2008-2009$

SOC sequestration in the relationship between percentage and induction organic C (Fig. 4) indicated that the soil under analysis was still unsaturated, even after a period of 20 years of contribution of crop residues, compost or both. The data obtained that revealed the maintenance of the stock level of SOC, is equal to zero changes, the amount subjected to the $\mathrm{C}$ contribution analysis in the soil was $2.04 \mathrm{Mg} \mathrm{C} \mathrm{ha}^{-1} \mathrm{yr}^{-1}$ (Fig. 4), which was a much lower percentage than Kong reported [31] (3.1 Mg C ha - 1 year - 1). It can be seen that after a period of 10 years of cultivation in Davis- California, in the conditions of Mediterranean climate, of Mandal [32] (3.41 Mg C ha - 1 year - 1) for a system of doublecultivated rice, of 36 years, in a subtropical climate, and Majumder [33] (3.56 Mg C ha -1 year - 1) for a 19-year-old rice wheat system in subtropical India [34].

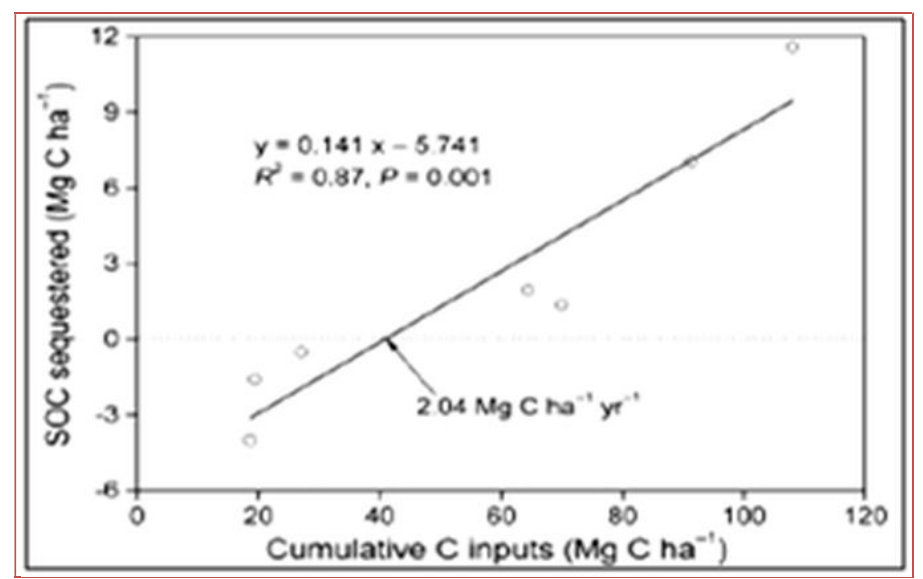

Fig. 4. SOC report after 20 years of application of inorganic fertilizers and compost [34] 


\section{Results and Discussion}

Sequestration of carbon in the soil can be achieved, in addition to adopting measures of a managerial and administrative nature, by using appropriate methods and technologies, called conservative, tillage, the most used worldwide being presented, in the system, in table 1 .

Tabel 1. Synthesis of conservative tillage technologies

\begin{tabular}{|c|c|c|c|c|}
\hline $\begin{array}{l}\text { Crt. } \\
\text { No. }\end{array}$ & $\begin{array}{c}\text { The technology } \\
\text { used }\end{array}$ & The work done & $\begin{array}{l}\text { Recommendations } \\
\text { for use }\end{array}$ & Effects of use \\
\hline 1 & $\begin{array}{l}\text { Paraplow tillage } \\
\text { technology }\end{array}$ & $\begin{array}{lr}\text { It cultivates the soil } \\
\text { without turning the } \\
\text { furrow } & \text { and } \\
\text { incorporating } & \text { the } \\
\text { vegetal } & \text { remains } \\
\text { superficially } & \end{array}$ & $\begin{array}{l}\text { On sloping terrain, } \\
\text { on sandy soils, on } \\
\text { saline terrain }\end{array}$ & $\begin{array}{lr}\text { Erosion } & \text { reduction, } \\
\text { water } & \text { conservation, } \\
\text { stopping } & \text { structural } \\
\text { degradation } & \text { and soil } \\
\text { dusting } & \end{array}$ \\
\hline 2 & $\begin{array}{l}\text { Conservative } \\
\text { tillage technology } \\
\text { with CIZEL }\end{array}$ & $\begin{array}{l}\text { The chisel processes } \\
\text { the soil to a depth of } \\
\text { max. } 40 \mathrm{~cm} \text { without } \\
\text { overturning the furrow, } \\
\text { causing fragmentation, } \\
\text { crushing and loosening }\end{array}$ & $\begin{array}{l}\text { Especially } \quad \text { on } \\
\text { sloping, saline, } \\
\text { thin-walled and } \\
\text { wind-eroded lands }\end{array}$ & $\begin{array}{l}\text { Reducing soil erosion, } \\
\text { water conservation in } \\
\text { the soil, reducing } \\
\text { structural degradation } \\
\text { and soil dusting. }\end{array}$ \\
\hline 3 & $\begin{array}{l}\text { Soil scarifier } \\
\text { technology }\end{array}$ & $\begin{array}{l}\text { Soil tillage at working } \\
\text { depths of } 0.50 \div 0.60 \mathrm{~m} \text {, } \\
\text { without turning the } \\
\text { furrow and a superficial } \\
\text { crushing }\end{array}$ & 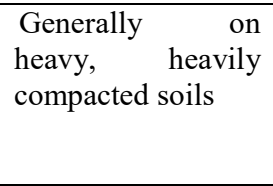 & $\begin{array}{l}\text { Elimination of the } \\
\text { impermeable layer of } \\
\text { soil (hardpan), } \\
\text { facilitates deep water } \\
\text { infiltration }\end{array}$ \\
\hline 4 & $\begin{array}{l}\text { Conservative } \\
\text { tillage technology } \\
\text { with } \\
\text { multifunctional } \\
\text { aggregates }\end{array}$ & $\begin{array}{l}\text { Deep loosening of the } \\
\text { soil, shredding and } \\
\text { leveling, preparation of } \\
\text { the germination bed, in } \\
\text { a single pass }\end{array}$ & $\begin{array}{l}\text { Spring or autumn, } \\
\text { on stubble, on all } \\
\text { types of soil } \\
\text { located on sloping } \\
\text { lands up to max. } 6^{\circ}\end{array}$ & $\begin{array}{l}\text { Water conservation in } \\
\text { the soil, reduction of } \\
\text { soil compaction, } \\
\text { halting the decline of } \\
\text { humidified organic } \\
\text { matter, structural } \\
\begin{array}{l}\text { degradation and soil } \\
\text { dusting }\end{array}\end{array}$ \\
\hline 5 & $\begin{array}{l}\text { Narrow strip } \\
\text { tillage technology }\end{array}$ & $\begin{array}{l}\text { Uncultivated tillage } \\
\text { and loosening in strips }\end{array}$ & $\begin{array}{l}\text { Preparation } r \text { of } \\
\text { myrtle, for later } \\
\text { sowing of weed } \\
\text { crops }\end{array}$ & $\begin{array}{l}\text { Water conservation in } \\
\text { soil, reduction of soil } \\
\text { processing, stopping } \\
\text { the decline of } \\
\text { humidified organic } \\
\text { matter }\end{array}$ \\
\hline 6 & $\begin{array}{l}\text { Technology for } \\
\text { soil compaction } \\
\text { simultaneously } \\
\text { with fertilization }\end{array}$ & $\begin{array}{l}\text { Compaction and partial } \\
\text { tillage at the same time } \\
\text { as fertilization with } \\
\text { chemical fertilizers }\end{array}$ & $\begin{array}{l}\text { Stubble processing, } \\
\text { for subsequent } \\
\text { sowing of weed } \\
\text { crops }\end{array}$ & $\begin{array}{l}\text { Decompaction, deep } \\
\text { aeration of soils, } \\
\text { removal of hardpan, } \\
\text { improvement of soil } \\
\text { permeability }\end{array}$ \\
\hline 7 & $\begin{array}{l}\text { Technology of } \\
\text { sowing and } \\
\text { fertilizing weeds } \\
\text { directly in the } \\
\text { stubble }\end{array}$ & $\begin{array}{l}\text { Partial surface } \\
\text { processing of myrtle, } \\
\text { sowing and fertilizing } \\
\text { of weed crops }\end{array}$ & $\begin{array}{l}\text { For sowing the } \\
\text { second crop after } \\
\text { straw or after } \\
\text { weeding crops in } \\
\text { uncultivated or } \\
\text { insufficiently } \\
\text { prepared soils for } \\
\text { spring sowing } \\
\end{array}$ & $\begin{array}{l}\text { Water conservation in } \\
\text { the soil, reduction of } \\
\text { soil processing, } \\
\text { conservation } \\
\text { organic matter }\end{array}$ \\
\hline
\end{tabular}


The development of technologies for this new type of agricultural exploitation could be stimulated by environmental subsidies, taking into account the fact that this results in a reduction of the environmental pollution of the global warming type [35]. The main innovative technologies for sequestering carbon in the soil that were developed by INMA are shown in figure 5.

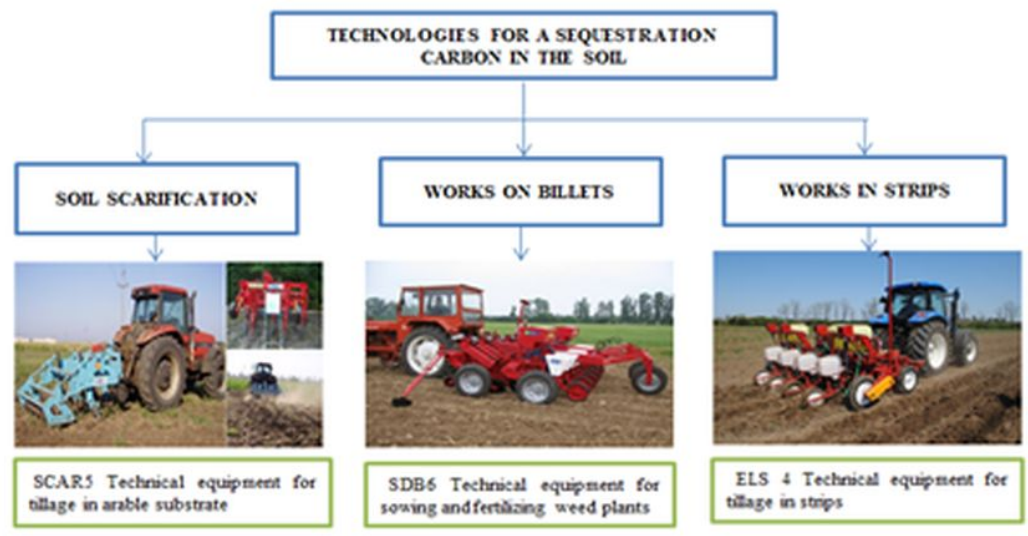

Fig. 5. Innovative technologies for carbon sequestration in the soil developed by INMA

The expansion, in practice, of soil conservation works differs from one country to another, the possibilities of mechanization are different depending on the increase of the capacity of tractors and agricultural machines and with the diversification of unloading, cultivating and sowing equipment. The technological systems of tillage have evolved a lot in the last decades, both in Romania and worldwide, evolution taking place both conceptually and in terms of extension of the conservative tillage methods.

\section{Conclusions}

At the global level, carbon management involves taking complex measures including actions on soil, atmosphere, water management, vegetation, resources and measures to combat climate change.

The possibility of carbon sequestration is mainly dominated by pedological factors that can establish the maximum physico-chemical delimitation when storing carbon in the soil.

these factors contain soil texture and clay mineralogy, depth, bulk density, aeration and proportion of coarse fragments.

One of the important directions approached worldwide to reduce carbon losses and implicitly the measures adopted for its sequestration in the soil, is the use of methods and technologies for carrying out conservation work on the soil, these being mainly: no tillage; strip tillage, mulch tillage, rotational tillage. 4. Worldwide, a series of conservative technologies have been developed and used, made with the appropriate technical equipment, the most used being presented in table 3 of this paper.

\section{Acknowledgement}

This paper was financed by a grant of the Romanian Education and Research Ministry, through Programme 1 - Development of the national research-development system, subprogramme 1.2 - Institutional performance - Projects for financing excellence in RDI, contract No. 16PFE. 


\section{Reference}

1. J. Demenois, E. Torquebiau, H. M. Arnoult, T. Eglin, Barriers and strategies to boost soil carbon sequestration in agriculture, Frontiers in Sustainable Food Systems, 4:37, 14 (2020).

2. G. Barancikova, J. Makovnikova, Comparison of two methods of soil organic carbon determination, Polish Journal of Soil Science 48 (1), pp. 47-56, (2015).

3. H. Zhang, X. Wang, Z. Feng, J. Pang, F. Lu, Z. Ouyang, H. Zheng, W. Liu, D. Hui, Soil temperature and moisture sensitivities of soil CO2 efflux before and after tillage in a wheat field of Loess Plateau, China, Journal of Environmental Sciences 23, pp 79-86 (2011).

4. O.W Heal, J.M Anderson, M.J. Swif, Plant litter quality and decomposition: an historical overview, Driven by nature: plant litter quality and decomposition. CAB International, Wallingford, UK, (1997).

5. K. Oorts, R. Merckx, E. Grehan, J. Labreuche, B. Nicolardot, Determinants of annual fluxes of $\mathrm{CO} 2$ and $\mathrm{N} 2 \mathrm{O}$ in longterm no-tillage and conventional tillage systems in northern France, Soil \& Tillage Research 95, pp. 133-148 (2007).

6. B.D. Soane, B.C. Ball, J. Arvidsson, G. Basch, F. Moreno, J. Roger-Estrade, No-till in northern, western and southwestern Europe: a review of problems and opportunities for crop production and the environment, Soil \& Tillage Research 118, 66-87 (2012)

7. N. La Scala, A. Lopes, K. Spokas, D. Archer, D.C. Reicosky, Short-term temporal changes of bare soil CO2 fluxes after tillage described by first-order decay models, European Journal of Soil Science 60, 258-264, (2009).

8. D.A. Coomes, R.B. Allen, N.A. Scott, C. Goulding, P. Beets, Designing systems to monitor carbon stocks in forests and shrublands, For. Ecol. Manag. 164 (1-3), pp. 89-108, (2002).

9. H.K. Gibbs, S. Brown, J.O. Niles, J.A. Foley, Monitoring and estimating tropical forest carbon stocks: making REDD a reality, Environ. Res. Lett. 2 (4), (2007).

10. I. Machar, J. Simon, K. Rejšek, V. Pechanec, J. Brus, H. Kilianová, Assessment of forest management in protected areas based on multidisciplinary research, Forests 7 (11), (2016).

11. V. Pechaneca, J. Purkytb, A. Benca, C. Nwaogua, L. Štěrbováb, P. Cudlínb, Modelling of the carbon sequestration and its prediction under climate change, Ecological Informatics 47: 50-54, (2018)

12. D.G. Goodenough, H. Chen, A. Dyk, J. Li, Multisensor data fusion for abovegroung carbon estimation, https://www.researchgate.net/publication/228338816, (2005).

13. R.A. Mandal, P. van Laake, Carbon sequestration in community forests: an eligible issue for CDM (a case study of Nainital, India), Banko Janakari 15 (2), pp. 53-61, (2005).

14. P. Vicharnakorn, R.P. Shrestha, M. Nagai, A.P. Salam, S. Kiratiprayoon, Carbon stock assessment using remote sensing and forest inventory data in Savannakhet, Lao PDR. Remote Sens. 6: 5452-5479, (2014).

15. A. Fiorini, R. Boselli, S.C. Maris, et al., May conservation tillage enhance soil $C$ and $N$ accumulation without decreasing yield in intensive irrigated croplands, Results from an eight-year maize monoculture, Agriculture Ecosystems \& Environment 296, (2020).

16. www.epa.gov/sequestration/local_scale.html 
17. www.attra.ncat.org/attra-pub/PDF/carbonsequestration.pdf, Agriculture, Climate Change and Carbon Sequestration, (2009).

18. www.epa.gov/sequestration/ local_scale.html, E.P.A., Local Scale: Carbon Pools in Forestry and Agriculture, (2008).

19. B. Minasny, Soil carbon to mitigate climate change, http://sydney.edu.au/news/ agriculture/1272.html?newsstoryid=15532, (2015).

20. E. Lin, G. Liping, J.U. Hui, Challenges to increasing the soil carbon pool of agroecosystems in China, Journal of Integrative Agriculture 17(4): 723-725, (2018).

21. C. Simota, S. Dumitru, O. Vizitiu, Guide to good agricultural practice for mitigating the effect of climate change on agriculture, Ghid de bune practici agricole pentru atenuarea efectului schimbărilor climatice asupra agriculturii (2014).

22. http://soco.jrc.ec.europa.eu., Sustainable agriculture and soil conservation Introduction, Correlation of soil degradation processes, non-hazardous agricultural practices and soil policies, (2009).

23. R. Lal, Carbon emission from farm operations, Environment International 30: 981990 (2004).

24. X. Ding, X. Han, Y. Liang, Y. Qiao, L. Li, N. Li, Changes in soil organic carbon pools after 10 years of continuous manuring combined with chemical fertilizer in a Mollisol in China, Soil Tillage Res. 122, 36-41, (2012).

25. R. Teodor, Soil conservation systems, Sisteme de lucrare pentru conservarea solului, Faculty of Agriculture, USAMV Cluj (2019).

26. Gibbs, H.K., Brown, S., Niles, J.O., Foley, J.A., Monitoring and estimating tropical forest carbon stocks: making REDD a reality, Environ. Res. Lett. 2 (4), 045023, http://dx.doi.org/10.1088/1748-9326/2/4/045023 (2007)

27. R. Derpsch, K. Moriya, Historical review of no-tillage cultivation of crops. Proceedings, First JIRCAS Seminar on soybean research, Brazil, JIRCAS Working Report 13, 1 - 18 (1998).

28. P.I. Moraru, T. Rusu, M. L. Sopterean, Control of soil works and their effect on erosion, water management and carbon sequestration, ProEnvironment 3: 541 - 548 (2010).

29. .L.G. Teixeira, M. M. Corradi, A. Fukuda, A. R. Panosso, et al., Soil and crop residue CO2-C emission under tillage systems in sugarcane-producing areas of southern Brazil, Scientia Agricola, On-line version ISSN 1678-992X, Sci. agric. (Piracicaba, Braz.) 70 (5) (2013).

30. G. Barancikova, J. Makovnikova, Comparison of two methods of soil organic carbon determination, Polish Journal of Soil Science 48 (1): 47-56 (2015).

31. A.Y.Y. Kong, J. Six, D.C. Bryant, R.F. Denison, C. van Kessel, The relationship between carbon input, aggregation, and soil organic carbon stabilization in sustainable, cropping systems, Soil Sci. Soc. Am. J. 69: 1078-1085 (2005).

32. B. Mandal, B. Majumder, T.K. Adhya, P.K. Bandyopadhyay, A. Gangopadhyay, D. Sarkar, M.C. Kundu, S.G. Choudhury, G.C. Hazra, S. Kundu, R.N. Samantaray, A.K. Misra, Potential of double cropped rice ecology to conserve organic carbon under subtropical climate, Glob. Chang. Biol. 14: 2139-2151 (2008).

33. B. Majumder, B. Mandal, P.K. Bandyopadhyay, A. Gangopadhyay, P.K. Mani, A.L. Kundu, D. Mazumdar, Organic amendments influence soil organic carbon pools and rice-wheat productivity, Soil Sci. Soc. Am. J. 72, 775-785 (2008). 
34. J. Fan, W. Ding, J. Xiang, S. Qin, J. Zhang, N. Ziadi, Carbon sequestration in an intensively cultivated sandy loam soil in the North China Plain as affected by compost and inorganic fertilizer application, Geoderma 230-231: 22-28 (2014).

35. D. Cujbescu, N. Ungureanu, V. Vlăduț, C. Persu, M.R. Oprescu, N.E. Gheorghiță, Field testing of compaction characteristics for farm tractor Universal 445, INMATEH - Agricultural Engineering, 59 (3): 245-252 (2019). 